\title{
Epigenetics in rheumatic diseases
}

\author{
Steffen Gay \\ From 21st European Pediatric Rheumatology (PReS) Congress \\ Belgrade, Serbia. 17-21 September 2014
}

With enormous speed novel data are emerging about regulating the expression of the genetically encoded information [1]. This highly complex regulatory network called epigenetics includes acetylation, methylation, phosphorylation, sumoylation and non-coding RNAs (ncRNA), such as miRNA and lncRNAs. Our laboratory is addressing over the past decade inflammatory rheumatic diseases [2], like rheumatoid arthritis (RA), AS, SSc and pulmonary hypertension and thereby searching for the regulation of pro-inflammatory cytokines [3,4], novel diagnostic signatures and new therapeutic targets. In this regard, DNA demethylation of RA synovial cells can be modulated by targeting specific enzymes [5]. Also, miRNA signatures for new response markers are in development [6].

\section{Disclosure of interest}

None declared.

Published: 17 September 2014

\section{References}

1. Dunham I, et al: An integrated encyclopedia of DNA elements in the human genome. Nature 2012, 489:57-74.

2. Gay S, Wilson AG: The emerging role of epigenetics in rheumatic diseases. Rheumatology 2013, (Epub ahead of print).

3. Brock M, et al: MicroRNA-18a enhances the IL-6 mediated production of the acute-phase proteins fibrinogen and haptoglobin in human hepatocytes. J Biol Chem 2011, 286:40142-50.

4. Trenkmann M, Brock M, Gay RE, Michel BA, Gay S, Huber LC: The TNFa-induced miR-18a activates rheumatoid arthritis synovial fibroblasts through a feedback loop in NF-kB signaling. Arthritis Rheum 2013, 65:916-27.

5. Neidhart M, Karouzakis E, Jüngel A, Gay RE, Gay S: Inhibition of spermidine/spermine N1-acetyltransferase (SSAT1) activity - a new therapeutical concept in rheumatoid arthritis. Arthritis Rheumatol 2014, [Epub ahead of print].

6. Filková M, et al: Association of circulating miR-223 and miR-16 with disease activity in patients with early rheumatoid arthritis. Ann Rheum Dis 2013, (Epub ahead of print).

Rheumatology, University Hospital, Zürich, Switzerland

doi:10.1186/1546-0096-12-S1-I12

Cite this article as: Gay: Epigenetics in rheumatic diseases. Pediatric Rheumatology 2014 12(Suppl 1):112.
() Biomed Central

(c) 2014 Gay; licensee BioMed Central Ltd. This is an Open Access article distributed under the terms of the Creative Commons Attribution License (http://creativecommons.org/licenses/by/4.0), which permits unrestricted use, distribution, and reproduction in any medium, provided the original work is properly cited. The Creative Commons Public Domain Dedication waiver (http://creativecommons.org/publicdomain/zero/1.0/) applies to the data made available in this article, unless otherwise stated. 